Ekonomis: Journal of Economics and Business, 4(2), September 2020, 257-267

Publisher by Lembaga Penelitian dan Pengabdian kepada Masyarakat Universitas Batanghari Jambi

Address: Jl. Slamet Ryadi, Broni-Jambi Kodepos: 36122

Website: http://ekonomis.unbari.ac.id, email: ekonomis.unbari@gmail.com

ISSN 2597-8829 (Online), DOI 10.33087/ekonomis.v4i2.148

\title{
Kekuatan Pasar (Market Power) dan Pangsa Ekspor Produk Ban (HS4011) Indonesia dan Negara Pesaing di Malaysia dan Filipina
}

\author{
Zainuddin \\ Fakultas Pertanian Universitas Batanghari \\ Correspondence email: zainuddin.ubr11@gmail.com
}

\begin{abstract}
The exporters of Indonesian and Thailand tire products have the same capability in price mark-ups in the Malaysian market. The price mark-up capability of tire exporters from Indonesia, Thailand and China is greater than the domestic tire industry in the Philippines. However, China has a greater share of tire exports in the Malaysian and Philippine markets and is likely related to China's ability to be able to increase the export composition of various types of tires. Indonesia needs to encourage the domestic tire industry to increase the production capacity of various types of tires through investment and relocation of the tire industry to Indonesia amid the downward trend in China's manufacturing industry. Need to develop tire products for the types of trucks, buses, tractors and heavy equipment that are often used in the construction, agriculture, mining and cargo transportation ports to enlarge market share in Malaysia and the Philippines because Indonesia has competitiveness from the aspect of raw materials. The potential export of various types of tires in the two export destination countries is a challenge to increase the number of exports of Indonesian tire products.
\end{abstract}

Keyword: market power; supply relation export; tires; export share; Indonesian country

\section{PENDAHULUAN}

Industri produk olahan karet domestik telah berkembang secara perlahan seiring dengan tumbuhnya ekspor terutama produk ban dengan kode HS 4011 (new pneumatic tires of rubber) ke berbagai negara. Jenis produk ban seperti ban sedan, ban truk dan bus, ban alat-alat berat, ban sepeda motor dan sepeda, mengalami peningkatan ekspor pada periode 2001-2017. Pesaing produk ban (kode HS 4011) berasal dari Thailand di kawasan Asean, sedangkan pesaing di luar Asean berasal dari Cina, Japan, Korea, dan Amerika Serikat. Indonesia mengekspor berbagai jenis produk karet (rubber prodcuts) seperti ban, ban dalam, pipa karet, alas dan pelapis dinding dari karet, conveyor belt, alat kesehatan dari karet, sarung tangan dan pakaian dari karet, dan berbagai jenis suku cadang automotif dan listrik dari karet. Namun nilai ekspor produk karet didominasi oleh berbagai jenis produk ban. Pada tahun 2019 tercatat nilai ekspor produk ban (kode HS 4011) Indonesia mencapai US\$1.648 juta, berbagai jenis suku cadang dan alat listrik dari karet (kode HS4016) sebesar US\$118 juta, berbagai jenis pakaian dan sarung tangan karet (kode HS4015) sebesar US\$268 juta, produk conveyor belt (kode HS4010) sebesar US\$66juta, dan berbagai jenis tabung, pipa, selang dari karet (kode HS4009) sebesar US\$26 juta, serta jenis lainnya dengan nilai relatif kecil (UN Comtrade, 2020).

Produk olahan lain dari karet yang mengalami perkembangan ekspor dengan tren kenaikan lemah $(1,73$ persen) adalah produk pakaian \& aksesori pakaian dari karet divulkanisasi termasuk juga berbagai jenis sarung tangan (gloves, mittens and mitts) dengan kode HS 4015 (Articles of apparel \& clothing accessories of vulcanised rubber). Ekspor produk tersebut stagnan dalam periode 2005-2010 dan tren menurun pada periode 2011-2015. Kemungkinan terkait dengan penurunan ekspor ke Amerika Serikat dengan pangsa ekspornya jauh lebih besar dari tujuan ekspor lainnya. Pesaing produksi olahan karet Indoensia khususnya kode HS 4015 (include gloves, mittens, and mitts) adalah Malaysia dan Thailand dari Asean, sedangkan di luar Asean berasal dari Cina.

Jenis produk karet yang mengalami peningkatan ekspor rata-rata relatif kecil ke sejumlah negara partner dalah produk code HS 4016 (articles of vulcanised rubber other than hard rubber). Dalam periode 2001-2014 ekspor produk karet tersebut hanya tumbuh 2.08 persen ke berbagai negara partner dan bahkan dalam 10 tahun terakhir mengalami penurunan ekspor. Negara tujuan ekspor tersebut hanya Germany, Netherlands, dan Japan yang mengalami peningkatan permintaan ekspor realatif tinggi, selebihnya relatif stagnan dan beberapa diantaranya menurun. Produk olahan karet ini adalah artikel lain dari karet yang divulkanisasi selain karet keras berupa karet selular (rubber cellular), penutup lantai dan tikar karet (floor coverings and mats), penghapus karet (erasers), gasket dan ring komponen mesin (gaskets and ring), sandaran kapal dan dermaga baik yang ditiup maupun tidak (boats and dermaga fender).

Dalam periode relatif panjang (lebih dari 25 tahun) Indonesia telah melakukan ekspor dalam volume relatif besar berbagai jenis ban (new pneumatic tyres of rubber) ke Amerika Serikat, Jepang, Jerman, Australia, Malaysia, dan Filipina. 
Disamping itu pengembangan tujuan ekspor dalam 5 sampai 10 tahun terakhir dengan volume lebih kecil telah dilakukan ke pasar potensial seperti wilayah Asia (India, Cina, Taiwan, Korsel, Arab Saudi, Uni Emirat Arab, dan Iran), wilayah Uni Eropa-Afrika (Belanda, Perancis, Inggris, Belgia, Italia, Turki, Rusia, dan Mesir), dan wilayah Amerika Latin yaitu Brazil (UN Comtrade, 2017). Industri olahan karet Indonesia diuntungkan dengan ketersediaan bahan baku karet alam domestik dengan harga relatif lebih rendah dibandingkan dengan industri sejenis di negara pengimpor karet alam dan olahan karet. Namun industri yang melakukan ekspor produk tersebut dikenakan tariff escalation dengan variasi berbeda antar negara untuk melindungi industri sejenis di pasar domestik negara-negara pengimpor. Fakta menunjukkan bahwa lebih dari 30 tahun mengembangkan industri olahan karet negara produsen karet alam hanya menempati ranking 6 sampai 12 negara eksportir terbesar olahan karet, sedangkan ranking 1 sampai 5 ditempati oleh Cina, Jepang, Amerika Serikat, Jerman, dan Korsel. Disini terlihat bahwa produk industri olahan karet Indonesia dan begitu juga Malaysia dan Thailand bersaing dengan industri domestik dan negara pemasok lainnya dalam pasar ekspor. Oleh karena jumlah produsen relatif sedikit baik di level domestik Indonesia maupun di negara pengimpor maka keputusan produsen dalam industri tersebut identik dengan oligopolistic market. Terkait dengan kemampuan masuk ke pasar ekspor di berbagai negara pengimpor diatas menimbulkan pertanyaan bagaimana perbandingan market power industri produk olahan karet (ban) antara Indonesia dengan negara pengekspor serta dengan industri sejenis di negara pengimpor. Secara khusus tujuan penelitian ini adalah membandingkan market power produk industri ban berbagai negara pengekspor ban (kode HS 4011) di negara pengimpor ban dan dikaitkan dengan pangsa ekspor.

Jeffrey dan Ware (2000) menjelaskan kekuatan pasar (market power) dapat dimiliki dan diukur pada suatu perusahaan dalam industri atau aggregat rata-rata industri. Kekuatan pasar diukur dengan dua pendekatan yaitu traditional structure conduct performance (SCP) dan New Empirical Industrial Organization (NEIO). Pendekatan SCP menggunakan data akuntansi mengenai keuntungan dan biaya untuk mengukur kekuatan pasar. Pendekatan ini dipandang relatif kurang sukses karena menentukan biaya marjinal didekati dengan data akuntansi dipertanyakan validitasnya. Pendekatan NEIO berusaha untuk meminimalkan penggunaan data akuntansi dalam mengukur kekuatan pasar dan biaya marjinal sekaligus. Pendekatan ini menggunakan fakta bahwa terdapat perbedaan reaksi produsen antara penerima harga (price takers) dengan produsen yang memiliki kekuatan pasar (market power) bila terjadi perubahan variabel eksogen dalam permintaan atau biaya.

Jika mengamati data selama beberapa periode pada suatu pasar output tertentu dimana dicirikan produk yang homogen maka dengan informasi data tersebut bisakah diungkapkan sejauh mana kekuatan pasar yang dikuasai perusahaan dalam industri atau level industri. Estimasi kekuatan pasar (market power) dapat dilakukan secara simultan untuk memperkirakan elastisitas permintaan, biaya marjinal, dan perilaku perusahaan atau perilaku level industri. Pendekatan ini disebut struktural karena melibatkan penggunaan teori untuk menentukan struktur permintaan dan penawaran, dan di dalam proses perilaku perusahaan atau level industri diperkirakan sejauh mana harga melebihi biaya marjinal dapat diidentifikasi.

Analisis market power suatu industri dilakukan lebih dahulu sebelum menilai besaran mark-up harga. Teknik ekonometrika dapat digunakan untuk menganalisis market power suatu industri sebagaimana Motta, 2003, Luckstead et al, 2015 dan Trangadisaikul, 2011. Penurunan fungsi profit industri ban negara pengimpor dan pengekspor terhadap kuantitas produksi dan kuantitas ekspor diperoleh perceived or effective marginal revenue sama dengan marginal cost $\left(\partial C^{j} / \partial q_{j}\right)$ sebagaimana berikut ini:

$p^{j}=\frac{\partial C^{j}\left(q_{j}^{d o m} ; X_{S}^{j}\right)}{\partial q_{j}^{d o m}}+\theta^{j} \varepsilon^{j} p^{j}$

$p^{j}=\left(\frac{1+\tau_{a v}^{j}}{2+\tau_{a v}^{j}}\right)\left(\tau_{s t}^{j}+\frac{\partial C^{I D N}\left(q_{j}^{I D N} ; X_{S}^{I D N} ; T^{j}\right)}{\partial q_{j}^{I D N}}\right)+\theta^{j . I D N} \varepsilon^{j} p^{j}$

$p^{j}=\left(\frac{1+\tau_{a v}^{j}}{2+\tau_{a v}^{j}}\right)\left(\tau_{s t}^{j}+\frac{\partial C^{k}\left(q_{j}^{k} ; X_{S}^{k} ; \operatorname{Tr}^{j}\right)}{\partial q_{j}^{k}}\right)+\theta^{j \cdot k} \varepsilon^{j} p^{j}$

dimana :

$\theta^{j} \quad$ adalah elastisitas konjektural ban domestik di negara $j$;

$\theta^{j . I D N}$ adalah elastisitas konjektural ban Indonesia di pasar ekspor negara $j$;

$\theta^{j . k} \quad$ adalah elastisitas konjektural ban negara $k$ di pasar ekspor negara $j$;

$\varepsilon^{j} \quad$ adalah pleksibilitas harga permintaan ban domestik di negara $j$;

$p^{j} \quad$ adalah harga ban di negara pengimpor $j$; 
$\tau^{j} \quad$ adalah tarif impor ban di negara pengimpor $j$ menggunakan advalorem $(a v) /$ specific tarrif $(s t)$;

$j \quad$ adalah negara pengimpor dan $k$ adalah negara pengekspor selain Indonesia.

Untuk memperoleh hubungan penawaran (supply relations) terlebih dahulu didefinisikan fungsi biaya marjinal (marginal cost) dan fungsi permintaan dengan mempertimbangkan koefisien permintaan dan penawaran serta elastisitas konjektural (conjectural elastisities)*. Fungsi biaya marjinal industri domestik negara pengimpor ban dan fungsi biaya marjinal industri pengekspor ban adalah:

$$
\begin{aligned}
& \frac{\partial C^{j}}{\partial q_{d o m}^{j}}={ }_{0}^{j} \theta+{ }_{1}^{j} \theta\left(q_{d o m}^{j}\right)+{ }_{2}^{j} \theta\left(X_{S}^{j}\right) \\
& \frac{\partial C^{I D N}}{\partial q_{j}^{I D N}}={ }_{0}^{I D N} \theta+{ }_{1}^{I D N . j} \cdot \theta\left(q_{j}^{I D N}\right)+{ }_{2}^{I D N} \theta\left(\tau^{j}\right)+{ }_{3}^{I D N} \theta\left(X_{S}^{I D N}\right) \\
& \frac{\partial C^{k}}{\partial q_{j}^{k}}={ }_{0}^{k} \theta+{ }_{1}^{k \cdot j} \cdot \theta\left(q_{j}^{k}\right)+{ }_{2}^{k} \theta\left(\tau^{j}\right)+{ }_{3}^{k} \theta\left(X_{S}^{k}\right)
\end{aligned}
$$

Fungsi permintaan terbalik ban oleh negara pengimpor $j$ merupakan permintaan produk asal pengekspor Indonesia, pengekspor negara $k$, produksi domestik negara $j$ dan negara lainnya:

$$
\begin{aligned}
p^{j}={ }_{0}^{j} \gamma+{ }_{1}^{j} \gamma\left(Q^{j}\right)+{ }_{2}^{j} \gamma\left(X_{D}^{j}\right) \\
Q^{j}=q_{j}^{d o m}+q_{j}^{I D N}+q_{j}^{k}+q_{j}^{O T H}
\end{aligned}
$$

dimana :

$\gamma \quad$ : koefisien fungsi permintaan terbalik di masing-masing negara pengimpor $j$;

$X_{D}^{j} \quad$ : adalah penggeser permintaan ban di negara pengimpor $j$;

$q_{j}^{\text {dom }}$ : adalah kuantitas produksi ban oleh industri domestik negara $j$;

$q_{j}^{I D N}$ : adalah kuantitas impor ban oleh negara $j$ dari negara Indonesia;

$q_{j}^{k} \quad$ : adalah kuantitas impor ban oleh negara $j$ dari negara $k$;

$q_{j}^{\text {OTH }}$ : adalah kuantitas impor ban oleh negara $j$ dari negara lainnya.

Dengan menggunakan first order conditions sebelumnya, fungsi biaya marjinal dan fleksibilitas permintaan maka dapat diturunkan model perilaku hubungan penawaran (supply relations) untuk ban di negara pengimpor (16) dan negara pengekspor (17 dan 18) berikut :

$p^{j}={ }_{0}^{j} \theta+{ }_{1}^{j} \theta\left(q_{\text {dom }}^{j}\right)+{ }_{2}^{j} \theta\left(X_{S}^{j}\right)+\theta^{j}{ }_{1}^{j} \gamma\left(Q^{j}\right)$

$p^{j}=\left(1+\tau_{a v}^{j}\right)\left\{{ }_{0}^{I D N . j} \theta+{ }_{1}^{I D N . j} \theta\left(q_{j}^{I D N}\right)+{ }_{2}^{I D N . j} \theta\left(\operatorname{Tr}^{j}\right)+{ }_{3}^{I D N} \theta\left(X_{S}^{I D N}\right)\right\}+\theta^{j . I D N}{ }_{1}^{j} \gamma\left(Q^{j}\right)$

$p^{j}=\left(1+\tau_{a v}^{j}\right)\left\{{ }_{0}^{k . j} \theta+{ }_{1}^{k . j} \theta\left(q_{j}^{k}\right)+{ }_{2}^{k . j} \theta\left(\operatorname{Tr}^{j}\right)+{ }_{3}^{k} \theta\left(X_{S}^{k}\right)\right\}+\theta^{j . k}{ }_{1}^{j} \gamma\left(Q^{j}\right)$

dimana :

$\theta^{j} \quad$ adalah koefisien elastisitas konjektural ban domestik negara pengimpor $j$;

${ }_{1}^{j} \gamma$ adalah koefisien pleksibilitas harga permintaan di negara $j$;

$X_{S}^{j} \quad$ adalah faktor penggeser penawaran ban negara pengekspor;

$\tau^{j} \quad$ adalah tarif impor ban di negara pengimpor $j$;

$\operatorname{Tr}^{j}$ adalah biaya biaya logistik ke negara pengimpor $j$;

Jika pleksibilitas permintaan ban di pasar negara $j$ adalah $\varepsilon^{j}$, elastisitas konjektural produk karet domestik negara pengimpor $j$ adalah $\theta^{j}$, elastisitas konjektural produk karet Indonesia di pasar ekspor negara $j$ adalah $\theta^{j . I D N}$, dan elastisitas konjektural produk karet negara $k$ di pasar ekspor negara $j$ adalah $\theta^{j . k}$ dapat diformulasikan kemampuan negara pengimpor dan negara pengekspor produk ban dalam melakukan mark-up harga sebagaimana berikut ini:

Industri ban di negara pengimpor $j: \quad \frac{p^{j}-M C^{j}}{p^{j}}=\theta^{j} \varepsilon^{j}$ 
Industri sejenis Indonesia di negara pengimpor $j: \frac{p^{j}-\left(\frac{1+\tau_{a v}^{j}}{2+\tau_{a v}^{j}}\right)\left(\tau_{s t}^{j}+M C^{I D N}\right)}{p^{j}}=\theta^{j . I D N} \varepsilon^{j}$

Industri sejenis negara $k$ di negara pengimpor $j: \frac{p^{j}-\left(\frac{1+\tau_{a v}^{j}}{2+\tau_{a v}^{j}}\right)\left(\tau_{s t}^{j}+M C^{k}\right)}{p^{j}}=\theta^{j . k} \varepsilon^{j}$

\section{METODE}

Dalam penelitian ini semuanya menggunakan data seri waktu tahunan (times series) periode 1985 sampai 2015 untuk komoditas karet alam spesifikasi teknis (TSNR). Data produk karet Indonesia khususnya kode HS 4011 (new pneumatic tyres of rubber) menggunakan rentang waktu dari tahun 1985 sampai dengan 2015. Data lainnya yang terkait dengan penelitian ini juga menggunakan rentang waktu yang sama. Sumber data berasal dari berbagai instansi pemerintah, asosiasi, dan lembaga internasional seperti Biro Pusat Statistik Pusat, Kementerian Perindustrian, Kementerian Perdagangan, UN Comtrad Statistics, World Trade Organization (WTO), World Bank, International Trade Rubber Group, International Tripartite Rubber Council, Malaysian Rubber Board, Indian Tyres and Manufactures Association, World Automotive Manufactures Association, China Ministry of Trade, Indian Ministry of Trade, International Organization of Motor Vehicle Manufacturers (OICA), dan sumber lainnya.

\section{Model strategi perdagangan ban di pasar negara pengimpor}

Model ekonometrika yang dibangun untuk menganalisis perdagangan produk ban (kode HS 4011) Indonesia dan negara pengekspor lainnya di pasar negara pengimpor $j$ (Malaysia dan Filipina) menggunakan simultaneous equations system karena pertimbangan perilaku yang saling terkait antara harga, permintaan, ekspor, impor dan produksi dalam perdagangan ban berikut ini.

1. Harga ban tingkat dealer negara pengimpor $\mathrm{j}$

$$
\begin{aligned}
& \mathrm{RPRP}_{\mathrm{jt}}=\mathrm{a} 0+\mathrm{a} 1 * \mathrm{QDRP}_{\mathrm{jt}}+\mathrm{a} 2 * \mathrm{RGDP}_{\mathrm{jt}}+\mathrm{a} 3 * \mathrm{QAUT}_{\mathrm{jt}}+\mathrm{a} 4 * \mathrm{POP}_{\mathrm{jt}}+\mathrm{a} 5 * \mathrm{RPOIL}_{\mathrm{jt}} \\
& +\mathrm{a} 6 * \mathrm{~T}_{\mathrm{t}} \\
& a_{2}, a_{3}, a_{4}, a_{6}>0 ; \quad a_{1}, a_{5}<0 \\
& \mathrm{RPRP}_{\mathrm{jt}}=\mathrm{b} 0+\mathrm{b} 1 * \mathrm{QRP}_{\mathrm{jt}}+\mathrm{b} 2 *\left(\mathrm{RPMRUB}_{\mathrm{jt}} / \mathrm{RPSBR}_{\mathrm{jt}}\right)+\mathrm{b} 3 * \mathrm{RPCB}_{\mathrm{jt}} \\
& +\mathrm{b} 4 * \mathrm{RPNGAS}_{\mathrm{jt}}+\mathrm{b} 5 * \mathrm{RWAGE}_{\mathrm{jt}}+\mathrm{b} 6 *\left(\mathrm{QDRPUS}_{\mathrm{jt}} /\left(\mathrm{TFRP}_{\mathrm{jt}}+1\right)\right) \\
& b_{1}>0 ; \quad b_{2}, b_{3}, b_{4}, b_{5}, b_{6}<0
\end{aligned}
$$


3. Permintaan ban negara pengimpor $\mathrm{j}$

$\mathrm{QDRP}_{\mathrm{jt}}=\mathrm{QRP}_{\mathrm{jt}}+\mathrm{MRP}_{\mathrm{jt}}-\mathrm{XRP}_{\mathrm{jt}}$

dimana:

QDRP $_{\text {jt }} \quad$ : permintaan ban negara pengimpor j tahun $\mathrm{t}(\mathrm{Ton})$

$\mathrm{QRP}_{\mathrm{jt}} \quad$ : produksi ban negara pengimpor $\mathrm{j}$ tahun $\mathrm{t}$ (Ton)

$\mathrm{MRP}_{\mathrm{jt}} \quad$ : impor ban negara pengimpor $\mathrm{j}$ tahun $\mathrm{t}$ (Ton)

$\mathrm{XRP}_{\mathrm{jt}} \quad$ : ekspor ban negara pengimpor $\mathrm{j}$ tahun $\mathrm{t}$ (Ton)

4. Produksi ban oleh industri domestik negara pengimpor $\mathrm{j}$

$\mathrm{QRP}_{\mathrm{jt}}=\mathrm{c} 0+\mathrm{c} 1 * \mathrm{RPRP}_{\mathrm{jt}}+\mathrm{c} 2 *\left(\mathrm{RPMRUB}_{\mathrm{jt}} / \mathrm{RPSBR}_{\mathrm{jt}}\right)+\mathrm{c} 3 * \mathrm{RPCB}_{\mathrm{jt}}$

$+\mathrm{c} 4 * \mathrm{RPNGAS}_{\mathrm{jt}}+\mathrm{c} 5 * \mathrm{RWAGE}_{\mathrm{jt}}+\mathrm{c} 6 * \mathrm{SHRMRP}_{\mathrm{jt}}$

dimana:

$c_{1}>0 ; \quad c_{2}, c_{3}, c_{4}, c_{5}, c_{6}<0$

$\mathrm{QRP}_{\mathrm{jt}} \quad$ : produksi ban negara pengimpor $\mathrm{j}$ tahun $\mathrm{t}$ (Ton)

$\mathrm{RPRP}_{\mathrm{jt}} \quad$ : harga ban domestik negara pengimpor $\mathrm{j}$ diproksi harga impor tahun $\mathrm{t}(\mathrm{US} \$ / \mathrm{Kg}$ )

RPMRUB $_{\mathrm{jt}}$ : harga impor karet alam negara pengimpor $\mathrm{j}$ tahun $\mathrm{t}(\mathrm{US} \$ / \mathrm{Kg}$ )

$\mathrm{RPSBR}_{\mathrm{jt}} \quad$ : harga karet sintetik negara pengimpor j tahun $\mathrm{t}(\mathrm{US} \$ / \mathrm{Kg})$

$\mathrm{RPCB}_{\mathrm{jt}} \quad$ : harga carbon black negara pengimpor $\mathrm{j}$ tahun $\mathrm{t}(\mathrm{US} \$ / \mathrm{Kg})$

RPNGAS $_{\text {jt }} \quad$ : harga gas alam negara pengimpor $\mathrm{j}$ tahun $\mathrm{t}(\mathrm{US} \$ / \mathrm{bbtu})$

RWAGE $_{\mathrm{jt}} \quad$ : upah industri manufaktur negara pengimpor $\mathrm{j}$ tahun $\mathrm{t}$

SHRMRP $_{\mathrm{jt}}$ : pangsa impor ban negara pengimpor $\mathrm{j}$ tahun $\mathrm{t}(\%)$

5. Impor ban negara pengimpor $\mathrm{j}$

$\mathrm{MRP}_{\mathrm{jt}}=\mathrm{XRPW}_{\mathrm{jt}}$

dimana:

$\mathrm{MRP}_{\mathrm{jt}} \quad$ : impor ban negara pengimpor $\mathrm{j}$ tahun $\mathrm{t}$ (Ton)

6. Ekspor ban dunia ke negara pengimpor $\mathrm{j}$

$\mathrm{XRPW}_{\mathrm{jt}}=\mathrm{XRPI}_{\mathrm{jt}}+\mathrm{XRPT}_{\mathrm{jt}}+\mathrm{XRPC}_{\mathrm{jt}}+\mathrm{XRPJ}_{\mathrm{jt}}+\mathrm{XRPKO}_{\mathrm{jt}}+\mathrm{XRPCA}_{\mathrm{jt}}+\mathrm{XRPOTH}_{\mathrm{jt}}$

dimana:

$\mathrm{XRPW}_{\mathrm{jt}} \quad$ : ekspor ban dunia ke negara pengimpor $\mathrm{j}$ tahun $\mathrm{t}$ (Ton)

$\mathrm{XRPI}_{\mathrm{jt}} \quad$ : ekspor ban Indonesia ke negara pengimpor $\mathrm{j}$ tahun $\mathrm{t}$ (Ton)

$\mathrm{XRPT}_{\mathrm{jt}} \quad$ : ekspor ban Thailand ke negara pengimpor $\mathrm{j}$ tahun $\mathrm{t}$ (Ton)

$\mathrm{XRPC}_{\mathrm{jt}} \quad$ : ekspor ban Cina ke negara pengimpor $\mathrm{j}$ tahun $\mathrm{t}$ (Ton)

$\mathrm{XRPJ}_{\mathrm{jt}} \quad$ : ekspor ban Jepang ke negara pengimpor $\mathrm{j}$ tahun $\mathrm{t}$ (Ton)

$\mathrm{XRPKO}_{\mathrm{jt}} \quad$ : ekspor ban Korsel ke negara pengimpor $\mathrm{j}$ tahun $\mathrm{t}$ (Ton)

$\mathrm{XRPCA}_{\mathrm{jt}} \quad$ : ekspor ban Kanada ke negara pengimpor j tahun $\mathrm{t}$ (Ton)

7. Supply relations ban negara pengekspor Indonesia ke negara pengimpor $j$

$$
\begin{aligned}
& \mathrm{RPRP}_{\mathrm{ijt}}=\mathrm{d} 0+\mathrm{d} 1 * \mathrm{XRP}_{\mathrm{ijt}}+\mathrm{d} 2 *\left(\mathrm{RPMRUB}_{\mathrm{ijt}} / \mathrm{RPSBR}_{\mathrm{ijt}}\right)+\mathrm{d} 3 * \mathrm{RPCB}_{\mathrm{ijt}} \\
& +\mathrm{d} 4 * \mathrm{RPNGAS}_{\mathrm{ijt}}+\mathrm{d} 5 * \mathrm{NTRUSD}_{\mathrm{it}}+\mathrm{d} 6 * \mathrm{~T}_{\mathrm{t}}+\mathrm{d} 7 * \mathrm{RWAGE}_{\mathrm{ijt}} \\
& +\mathrm{d} 8 *\left(\mathrm{QDRP}_{\mathrm{jt}} /\left(\mathrm{TFRP}_{\mathrm{jt}}+\mathbf{1}\right)\right) \\
& d_{1}, d_{2}, d_{3}, d_{4}, d_{5}, d_{7}>0 ; \quad d_{8}<0 ; \quad d_{6}><0
\end{aligned}
$$




$$
\begin{array}{ll}
\text { QDRP }_{j t} & \text { : permintaan ban negara } \mathrm{j} \text { tahun } \mathrm{t} \text { (Ton) } \\
\mathrm{TFRP}_{\mathrm{jt}} & \text { : tarif impor ban negara } \mathrm{j} \text { tahun } \mathrm{t}(\%) \\
\mathrm{i} & \text { : negara pengekspor ban } \\
\mathrm{j} & \text { : negara pengimpor ban }
\end{array}
$$

8. Persamaan ekspor ban ke negara pengimpor $\mathrm{j}$

$$
\begin{aligned}
\mathrm{XRP}_{\mathrm{ijt}}=\mathrm{e} 0 & +\mathrm{e} 1 *\left(\mathrm{RPXRP}_{\mathrm{ijt}} /\left(\mathrm{TFRP}_{\mathrm{jt}}+\mathbf{1}\right)\right)+\mathrm{e} 2 * \mathrm{NTRUSD}_{\mathrm{it}}+\mathrm{e} 3 *\left(\mathrm{RPMRUB}_{\mathrm{it}} / \mathrm{RPSBR}_{\mathrm{it}}\right) \\
+ & \mathrm{e} 4 * \mathrm{RWAGE}_{\mathrm{it}}+\mathrm{e} 5 * \mathrm{QRP}_{\mathrm{jt}}+\mathrm{e} 6 * \mathrm{QAUT}_{\mathrm{jt}}+\mathrm{e} 7 * \mathrm{~T}_{\mathrm{t}}+\mathrm{e} 8 * \mathrm{XRP}_{\mathrm{ijt}-1} \\
& e_{1}, e_{2}, e_{6}>0 ; \quad e_{3}, e_{4}, e_{5}<0 ; \quad e_{7}><0 ; \quad 0<e_{8}<1
\end{aligned}
$$

dimana:

$\mathrm{XRP}_{\mathrm{ijt}} \quad$ : ekspor ban negara i ke negara j tahun $\mathrm{t}$ (Ton)

RPXRP $_{i j t} \quad$ : harga ekspor ban negara i ke negara j tahun $\mathrm{t}(\mathrm{US} \$ / \mathrm{Kg})$

TFRP $_{\mathrm{jt}} \quad$ : tarif impor ban negara $\mathrm{j}$ tahun $\mathrm{t}(\%)$

NTRUSD $_{\text {it }}$ : nilai tukar mata uang negara i terhadap US Dollar tahun $\mathrm{t}$

RPMRUB $_{\text {it }}$ : harga karet alam di negara i tahun $\mathrm{t}(\mathrm{US} \$ / \mathrm{Kg})$

RPSBR $_{\text {it }} \quad$ : harga karet sintetik di negara i tahun $\mathrm{t}(\mathrm{US} \$ \mathrm{Kg})$

RWAGE $_{\text {it }} \quad$ : upah industri manufaktur negara i tahun $\mathrm{t}$

$\mathrm{QRP}_{\mathrm{jt}} \quad$ : produksi ban negara pengimpor $\mathrm{j}$ tahun $\mathrm{t}$ (Ton)

QAUT $_{j \mathrm{j}} \quad$ : produksi kenderaan automotif negara pengimpor $\mathrm{j}$ tahun $\mathrm{t}$ (Juta Unit)

$\mathrm{XRP}_{\mathrm{ijt}-1} \quad$ : ekspor ban negara i ke negara j tahun $\mathrm{t}-1$ (Ton)

\section{Identifikasi dan Estimasi Model}

Model sistem persamaan yang digunakan dalam penelitian teridentifikasi berlebih (over identified) sebagaimana Tabel 1. Berdasarkan order condition, suatu persamaan dapat diidentifikasi jika jumlah total variabel yang keluar dari persamaan harus sama dengan atau lebih besar dari jumlah variabel current endogenous dikurangi satu. Identifikasi model struktural berdasarkan order condition menggunakan formula sebagaimana Koutsoyiannis (1977). Jika jumlah persamaan (current endogenous variables) dalam model $(\mathrm{G})$, jumlah seluruh peubah (endogenous dan exogenous variables) yang terdapat dalam suatu persamaan $(\mathrm{M})$ dan jumlah total variabel dalam model atau current endogenous and predetermined $(\mathrm{K})$ maka $(\mathrm{K}-\mathrm{M})=(\mathrm{G}-1)$ dikatakan exactly identified, $(\mathrm{K}-\mathrm{M}) \geq(\mathrm{G}-1)$ dikatakan over identified dan $(\mathrm{K}-\mathrm{M}) \leq(\mathrm{G}-1)$ dikatakan unidentified. Hasil identifikasi setiap persamaan dalam model yang digunakan adalah teridentifikasi berlebih (over identified).

Tabel 1. Hasil identifikasi model strategi perdagangan ban di negara pengimpor

\begin{tabular}{lcccc}
\hline \multirow{2}{*}{$\begin{array}{c}\text { Model dengan negara } \\
\text { pengimpor }\end{array}$} & \multicolumn{4}{c}{ Model Strategi Perdagangan Produk Karet di Negara Pengimpor } \\
\cline { 2 - 5 } & $\begin{array}{c}\text { Variabel endogen } \\
\text { dalam model }\end{array}$ & $\begin{array}{c}\text { Variabel endogen dan } \\
\text { eksogen dalam persamaan }\end{array}$ & $\begin{array}{c}\text { Total variabel } \\
\text { dalam model }\end{array}$ & $\begin{array}{c}\text { Identifikasi } \\
(\mathrm{K})\end{array}$ \\
\hline Malaysia & 12 & $(\mathrm{M})$ & 31 & over identified \\
Filipina & 14 & 9 & 33 & over identified \\
\hline
\end{tabular}

Jika hasil identifikasi setiap persamaan dalam model teridentifikasi berlebih (over identified) tidak bisa menggunakan ILS Method karena hasil estimasinya tidak unik. Koutsoyiannis (1977) menyarankan menggunakan pilihan metode LIML (Limited Information Likelihood), FIML (Full Information Maximum Likelihood), 2SLS (Two Stage Least Squares) atau 3SLS (Three Stage Least Squares). Secara umum metode 3SLS (Three Stage Least Squares Method) menghasilkan hasil estimasi koefisien yang lebih efisien secara asimtotik dibandingkan 2SLS (Two Stage Least Squares Method). Namun metode 3SLS lebih sensitif terhadap perubahan dalam spesifikasi dan membutuhkan data yang lebih banyak.

\section{HASIL DAN PEMBAHASAN}

Model strategi perdagangan produk ban pada pasar ekspor di Malaysia dan Filipina secara terpisah dilakukan estimasi mengggunakan metode Two Stage Least Squares (2SLS). Sebagian besar hasil estimasi setiap persamaan dalam model dinilai sesuai dengan teori ekonomi dan memenuhi kriteria statistik. Estimasi koefisien pada persamaan harga ban 
tingkat dealer digunakan untuk memperoleh fleksibilitas harga ban. Selanjutnya secara bersama dengan estimasi koefisien pada persamaan supply relations produksi domestik negara pengimpor dan export supply relations negara pengekspor digunakan untuk memperoleh elastisitas konjektural dan besaran mark-up harga ban. Fleksibilitas dan elastisitas ditambah dengan faktor lain digunakan untuk analisis ekspor ban Indonesia dan negara pengekspor ban lainnya pada pasar ekspor di Amerika Serikat, Australia, Jepang, Malaysia dan Filipina.

Indeks Lerner dapat digunakan untuk mengukur mark-up harga yang melebihi biaya marjinal dilakukan negara pengekspor dan industri domestik negara pengimpor. Pengukuran seberapa besar mark-up harga dihitung dengan mengalikan fleksibilitas harga dengan elastisitas konjektural. Menurut Luckstead, et.al (2015) bahwa kemampuan suatu industri memanfaatkan kekuatan oligopoli dan menentukan harga melebihi biaya marjinal (mark-up) tergantung dari kondisi penawaran (elastisitas konjektural) dan permintaan (fleksibilitas harga).

Pengukuran fleksibilitas harga, elastisitas konjektural dan besaran mark-up harga oleh industri domestik negara pengimpor dan industri sejenis negara pengekspor ban menggunakan sistem persamaan simultan (simultaneous equations system). Luckstead, et. al (2015) menyatakan ada empat kemungkinan bentuk kompetisi pasar. Pertama, situasi melakukan kolusi sempurna (perfect collution) dimana produsen bertindak sebagai monopoli. Konjektural variasi sama dengan satu dan pangsa pasar juga sama dengan satu sehingga elastisitas konjektural sama dengan satu. Akibatnya kemampuan markup harga ditentukan oleh hanya fleksibilitas permintaan. Kedua, situasi dalam kompetisi cournot (cournot competition). Konjektural variasi sama dengan satu dan pangsa pasar kecil dari satu. Akibanya kemampuan mark-up harga tergantung pada fleksibilitas permintaan dan pangsa pasar (market share). Ketiga, situasi beroperasi dalam struktur pasar fleksibel ( $a$ fully plexible market structure) dimana kemampuan melakukan mark-up harga ditentukan oleh elastisitas konjektural dibobot dengan fleksibilitas permintaan. Keempat, situasi dalam kompetisi sempurna (perfect competition) dimana pangsa pasar begitu kecil sehingga tidak cukup kuat mempengaruhi harga sehingga elastisitas konjektural sama dengan nol dan mark-up harga juga sama dengan nol atau harga sama dengan biaya marjinal. Bentuk kompetisi pada pasar ekspor produk karet (ban) di Amerika Serikat lebih mendekati setuasi struktur pasar pleksibel (a fully plexible market structure) karena pilihan asal produk dan merek juga tersedia setiap saat dan tidak dalam bentuk monopoli melainkan terdapat pilihan walaupun jumlahnya terbatas.

\section{Kekuatan pasar dan pangsa ekspor ban negara pengekspor di Malaysia}

Pasar ban di Malaysia relatif lebih kecil dibandingkan dengan pasar produk sejenis di Jepang, Australia dan Amerika Serikat. Malaysia mengembangkan industri pengolahan ban yang sebagian besar ditujukan untuk pemenuhan permintaan domestik dan sisanya sebesar 24,08 persen di ekspor ke berbagai negara seperti Filipina, Jepang, Australia, Amerika Serikat dan Uni Eropa. Kebutuhan bahan baku karet alam mayoritas di impor dari negara-negara ASEAN. Produksi ban domestik Malaysia dihasilkan oleh perusahaan besar industri karet seperti Toyo Tires Malaysia, Goodyear Malaysia Bhd, Continental Sime Tyre, Frienship Rubber Industry, Sunrich Tyre, Kajang Tayar, dan lainnya. Kemampuan produksi ban Malaysia mencapai rata-rata 89995 ton dalam periode 1985 sampai 2015 dan cenderung menurun sejak tahun 2006 sampai 2015 dengan pertumbuhan rata-rata sebesar -1,92 persen (UN Comtrade, 2017). Permintaan ban di Malaysia melebihi kemampuan produksi dan keadaan ini mendorong kenaikan impor Malaysia dari sejumlah negara. Pada periode 1985 sampai 2015 impor produk tersebut mencapai rata-rata 26.635 ton per tahun dengan pertumbuhan rata-rata sebesar 10,57 persen. Negara pengekspor ban ke Malaysia seperti Cina, Indonesia, Thailand, Korea Selatan, India, Singapore dan lainnya. Namun yang dipertimbangkan dan relevan tetap kontinyu melakukan ekspor dalam periode 30 tahun terakhir adalah negara pengekspor Indonesia, Thailand dan Cina.

Estimasi fleksibilitas harga, elastisitas konjektural dan besaran mark-up harga ban disajikan pada Tabel 2. Fleksibilitas harga ban di Malaysia sebesar -0,3967 (elastisitas permintaan berkisar -2,52) menunjukkan bahwa produk karet di pasar Malaysia respons harganya lebih elastis. Sensitivitas harga yang relatif tinggi tersebut kemungkinan menarik perhatian produsen ban di luar Malaysia sehingga mereka membangun anak perusahaan (subsidiaries) di Malaysia seperti Toyo Tires Malaysia, Goodyear Malaysia Bhd, dan Continental Sime Tyre. Elastisitas konjektural ban domestik di Malaysia menunjukkan besaran atau magnitude sebesar 1,000. Elastisitas tersebut lebih besar dibandingkan dengan elastisitas konjektural ban asal impor yang berkisar antara 0,64 sampai dengan 0,89.

Sebagaimana Tabel 2 terlihat bahwa kemampuan negara pengekspor Indonesia dan Thailand menentukan harga melebihi biaya marjinal (mark-up) relatif sama dibandingkan industri sejenis di Malaysia, sedangkan Cina lebih rendah. Industri ban domestik di Malaysia melakukan mark-up harga sebesar 24 persen, sedangkan Indonesia hanya 25 persen, Thailand 24 persen dan Cina 19 persen. Industri ban Malaysia dilindungi dengan tarif impor rata-rata sebesar 26,22 persen dalam periode 1985 sampai 2015 (World Bank, 2017). Namun pengenaan tarif impor tersebut cenderung dengan tren 
menurun. Rata-rata tarif impor ban di Malaysia sekitar 30 persen dalam periode 1985 sampai 1996. Tarif impor tersebut turun menjadi rata-rata sekitar 28,26 persen periode 1997 sampai 2002 dan turun lagi menjadi rata rata sebesar 21,80 persen periode 2003 sampai 2015. Tarif impor berbagai jenis ban lebih tinggi dibandingkan tarif karet alam. Pengenaan tarif impor bagi produk hasil industri manufaktur selalu lebih tinggi dibandingkan dengan bahan baku atau input bagi industri sebagai bentuk dari praktek esclation tariffs yang diberlakukan negara pengimpor (Ishikawa dan Lee, 1997). Tarif yang lebih tinggi tersebut menghambat arus ekspor produk ban ke pasar Malaysia. Namun dengan pemberlakukan AFTA memberika peluang bagi Indonesia dan negara pesaing meningkatkan ekspor produk ban ke pasar Malaysia dan faktor penting selanjutnya yang berperan adalah daya saing (Arianti dan Lubis, 2011; Kahfi, 2016).

Tabel 2. Fleksibilitas permintaan, elastisitas konjektural, besaran mark-up, pangsa dan komposisi ekspor pada industri ban di Malaysia dan negara pengekspor

\begin{tabular}{|c|c|c|c|c|c|c|c|}
\hline \multirow{2}{*}{$\begin{array}{c}\text { Negara } \\
\text { Pengimpor } \\
(j)\end{array}$} & \multirow{2}{*}{$\begin{array}{c}\text { Negara } \\
\text { Pengekspor } \\
(h)\end{array}$} & \multirow[t]{2}{*}{ Periode } & \multicolumn{3}{|c|}{$\begin{array}{c}\text { Fleksibilitas Permintaan dan Elastisitas } \\
\text { konjektural }\end{array}$} & \multicolumn{2}{|c|}{ Markup } \\
\hline & & & $\varepsilon^{j}$ & $\theta^{j}$ & $\theta^{j . h}$ & $\theta^{j} \varepsilon^{j}$ & $\theta^{j . h} \varepsilon^{j}$ \\
\hline \multirow[t]{12}{*}{ Malaysia } & & & 0,3967 & 0,6160 & & 0,2443 & \\
\hline & Indonesia & 2006-2015 & & & 0,6470 & & 0,2567 \\
\hline & Thailand & 2006-2015 & & & 0,6100 & & 0,2420 \\
\hline & Cina & $2006-2015$ & & & 0,4870 & & 0,1932 \\
\hline & & & Pangsa & & Komposisi & r (\%) & \\
\hline & & & Ekspor & 401110 & 401120 & 401140 & 401150 \\
\hline & Indonesia & 2006-2010 & 17,46 & 96,08 & 2,67 & 0,97 & \\
\hline & & 2011-2015 & 17,19 & 94,63 & 3,11 & 1,91 & \\
\hline & Thailand & 2006-2010 & 30,38 & 54,74 & 32,81 & 11,48 & 0,97 \\
\hline & & 2011-2015 & 25,79 & 46,56 & 27,67 & 14,40 & 11,37 \\
\hline & Cina & $2006-2010$ & 21,65 & 30,37 & 58,42 & 4,91 & 6,29 \\
\hline & & 2011-2015 & 40,14 & 30,22 & 63,88 & 3,40 & 2,49 \\
\hline
\end{tabular}

Sumber: Olahan data penelitian

Keterangan:

Fleksibilitas permintaan pasar ban di Malaysia $\left(\varepsilon^{j}\right)$ dimana $j=$ Malaysia.

Elastisitas konjektural ban yang di produksi di Malaysia $\left(\theta^{j}\right)$ dimana $j=$ Malaysia.

Elastisitas konjektural ban yang di ekspor keMalaysia $\left(\theta^{j . h}\right)$ dimana $h=$ Indonesia, Thailand dan Cina.

Jenis ban untuk mobil penumpang dengan kode HS 401110. Jenis ban untuk bus, truk, alat-alat berat dengan

Kode HS 401120. Jenis ban untuk sepeda motor dengan kode HS 401140 dan untuk sepeda kode HS 401150.

Industri karet Indonesia dan Thailand diuntungkan dengan kelimpahan bahan baku karet alam, upah tenaga kerja relatif lebih rendah, dan biaya pengapalan (shipping cost) lebih kecil ke pelabuhan tujuan di Malaysia. Sebagian input bahan lainnya (karet sintetis, carbon black, silica dan lain-lain) sebagian besar harus di impor. Sebaliknya industri karet Cina dihadapkan dengan upah tenaga kerja yang semakin tinggi, biaya pengapalan lebih besar dan biaya bahan baku karet alam lebih tinggi karena pengenaan tarif impor karet alam sekitar 20 persen.

Pangsa ekspor ban Indonesia relatif lebih kecil dibandingkan pangsa Thailand dan Cina pada pasar ekspor di Malaysia. Sebagaimana Tabel 2 pangsa ekspor ban Indonesia tidak paralel dengan kemampuan melakukan mark-up harga. Faktor lain yang kemungkinan mempengaruhi pangsa ekspor adalah komposisi ekspor ban yang dilakukan oleh negara pengekspor. Indonesia hanya dominan mengekspor jenis ban mobil penumpang (HS401110), sedangkan komposisi ekspor ban Thailand dan Cina relatif lebih lengkap meliputi jenis ban mobil penupang (HS401110), jenis ban untuk truk, bus, alat-alat berat (HS401120), jenis ban untuk sepeda motor (HS401140) dan jenis ban sepeda (HS401150). Efek dari komposisi ekspor tersebut kemungkinan mendorong peningkatan pangsa ekspor ban Thailand dan Cina pada pasar ekspor di Malaysia.

Berdasarkan potensi ekspor masih terbuka peluang meningkatkan ekspor produk ban untuk pasar Malaysia. Data ITC export potential map (2020) menunjukkan potensi ekspor jenis ban untuk mobil (kode HS 401110) mencapai US $\$ 109,2$ juta (aktual ekspor US $\$ 61,9$ juta), jenis ban untuk bus, truk dan lori (kode HS 401120) mencapai US $\$ 9,9$ juta (aktual ekspor US\$2,2 juta), jenis ban untuk berbagai jenis sepeda motor (kode HS 401140) mencapai US\$11,3 juta (aktual ekspor US\$5,5 juta), dan jenis ban untuk sepeda (kode HS 401150) mencapai US\$1,0 juta (aktual ekspor US\$0,288 juta). Dilihat dari potensi ekspor maka pesaing kuat jenis ban untuk mobil (motor car) adalah Thailand, Cina 
dan Vietnam, sedangkan pasar ekspor jenis ban untuk bus, truk dan lori dikuasai lebih dominan oleh Cina dan Thailand. Indonesia cukup menguasai pasar ekspor jenis ban untuk sepeda motor di Malaysia dengan pesaing kuat Thailand, Vietnam dan Cina. Indonesia juga mengusai ekspor ban sepeda di pasar Malaysia dengan pesaing ketat berasal Thailand, Vietnam, India dan Taiwan.

\section{Kekuatan pasar dan pangsa ekspor ban negara pengekspor di Filipina}

Pasar ban di Filipina relatif lebih kecil dibandingkan dengan pasar produk sejenis di Malaysia, Jepang, Australia dan Amerika Serikat. Filipina mengembangkan industri pengolahan ban yang sebagian besar ditujukan untuk permintaan domestik. Kebutuhan bahan baku karet alam berasal dari domestik dan impor dari negara-negara ASEAN. Produksi produk karet (ban) domestik Filipina dihasilkan oleh perusahaan besar industri karet seperti Yokohama, Bridgeston, Leo Tire, Sun Master, dan lainnya. Kemampuan produksi ban Filipina mencapai rata-rata 4.477 ton dalam periode 1985 sampai 2015 dan cenderung menurun sejak tahun 2000 sampai 2015 dengan pertumbuhan rata-rata sebesar -2,69 persen (UN Comtrade, 2017). Permintaan ban di Filipina mencapai rata-rata 55067 ton periode 1985 sampai 2015 dengan pertumbuhan rata-rata sebesar 8,29 persen periode 2000 sampai 2015. Permintaan tersebut melebihi kemampuan produksi sehingga mendorong kenaikan impor Filipina dari sejumlah negara. Pada periode 1985 sampai 2015 impor produk tersebut mencapai rata-rata 50590 ton per tahun dengan pertumbuhan rata-rata sebesar 202.34 persen periode 2000 sampai 2015. Negara pengekspor ban ke Filipina seperti Cina, Jepang, Indonesia, Thailand, Malaysia, India, Singapore dan lainnya. Namun yang dipertimbangkan dan relevan tetap kontinyu melakukan ekspor dalam periode 30 tahun terakhir adalah negara pengekspor Indonesia, Thailand, Cina dan India.

Estimasi fleksibilitas harga, elastisitas konjektural dan besaran mark-up harga disajikan pada Tabel 3. Fleksibilitas harga ban di Filipina sebesar -1,5030 (elastisitas permintaan berkisar -0,67) menunjukkan bahwa ban di pasar Filipina respons harganya kurang elastis. Sensitivitas harga yang relatif rendah tersebut kemungkinan tidak menarik perhatian produsen ban dari luar Filipina sehingga mereka masih belum tertarik membangun anak perusahaan (subsidiaries) di Filipina melalui investasi. Hanya sedikit perusahaan besar yang telah berproduksi di Filipina seperti Yokohama Tyre Manufacturing.

Elastisitas konjektural ban domestik di Filipina menunjukkan besaran atau magnitude sebesar 0,1315. Elastisitas tersebut lebih kecil dibandingkan dengan elastisitas konjektural ban asal impor dari Cina 0,1667, Indonesia 0,1667 dan Thailand 0,1663, tetapi lebih beasr dari India 0,1055. Sebagaimana Tabel 12 terlihat bahwa kemampuan negara pengekspor Indonesia, Thailand dan Cina menentukan harga melebihi biaya marjinal (mark-up) lebih besar dibandingkan industri sejenis di Filipina, namun negara pengekspor India lebih kecil dibanding Filipina. Industri ban domestik di Filipina melakukan mark-up sebesar 19 persen, sedangkan Indonesia 25 persen, Thailand 25 persen, Cina 25 persen, dan India 15 persen. Industri ban Filipina dilindungi dengan tarif impor rata-rata sebesar 19,29 persen dalam periode 1985 sampai 2015 (World Bank, 2017). Namun pengenaan tarif impor tersebut cenderung dengan tren menurun. Rata-rata tarif impor ban di Filipina sekitar 30 persen dalam periode 1985 sampai 1997. Tarif impor tersebut turun menjadi rata-rata sekitar 17,42 persen periode 1998 sampai 2003. Tren penurunan tarif terus berlanjut hingga sebesar 10 persen periode 2004 sampai 2010 dan 9,20 persen periode 2011 sampai 2015. Dengan adanya kesepakatn ASEAN Free Trade Area maka tarif tersebut diberlakukan zero tariffs sebagai wujud dari deregulasi perdagangan wilayah ASEAN. Berbagai penelitian sebelumnya menunjukkan peningkatan arus ekspor dan perekonomian pada setuasi hambatan jika tarif diturunkan (Erwidodo, 1999; Arianti dan Lubis, 2011).

Industri karet Indonesia dan Thailand diuntungkan dengan kelimpahan bahan baku karet alam, upah tenaga kerja relatif lebih rendah, dan sebaliknya biaya pengapalan (shipping cost) lebih tinggi ke pelabuhan tujuan di Filipina. Sebagian input bahan lainnya (karet sintetis, carbon black, silica dan lain-lain) sebagain besar harus di impor. Sebaliknya industri ban India dihadapkan dengan biaya pengapalan (shipping cost) lebih tinggi ke pelabuhan tujuan di Filipina dan khususnya industry ban Cina dan India juga dihadapkan dengan biaya bahan baku karet alam lebih tinggi karena pengenaan tarif impor karet alam sekitar 20 persen di Cina dan 20 persen di India. 
Tabel 3. Fleksibilitas permintaan, elastisitas konjektural, besaran mark-up, pangsa dan komposisi ekspor pada industri ban di Filipina dan negara pengekspor

\begin{tabular}{|c|c|c|c|c|c|c|c|}
\hline \multirow{2}{*}{$\begin{array}{c}\text { Negara } \\
\text { Pengimpor } \\
(j)\end{array}$} & \multirow{2}{*}{$\begin{array}{c}\text { Negara } \\
\text { Pengekspor } \\
(h)\end{array}$} & \multirow[t]{2}{*}{ Periode } & \multicolumn{3}{|c|}{$\begin{array}{c}\text { Fleksibilitas Permintaan dan Elastisitas } \\
\text { konjektural }\end{array}$} & \multicolumn{2}{|c|}{ Markup } \\
\hline & & & $\varepsilon^{j}$ & $\theta^{j}$ & $\theta^{j . h}$ & $\theta^{j} \varepsilon^{j}$ & $\theta^{j . h} \varepsilon^{j}$ \\
\hline \multirow[t]{15}{*}{ Filipina } & & & 1,5030 & 0,1315 & & 0,1976 & \\
\hline & Indonesia & 2006-2015 & & & 0,1667 & & 0,2505 \\
\hline & Thailand & 2006-2015 & & & 0,1663 & & 0,2500 \\
\hline & Cina & 2006-2015 & & & 0,1667 & & 0,2505 \\
\hline & India & 2006-2015 & & & 0,1055 & & 0,1586 \\
\hline & & & Pangsa & & Komposisi & or $(\%)$ & \\
\hline & & & Ekspor & 401110 & 401120 & 401140 & 401150 \\
\hline & Indonesia & 2006-2010 & 17,49 & 44,87 & 53,42 & 1,61 & \\
\hline & & 2011-2015 & 15,65 & 45,56 & 49,92 & 4,43 & \\
\hline & Thailand & 2006-2010 & 14,09 & 32,10 & 56,14 & 11,35 & \\
\hline & & 2011-2015 & 12,02 & 29,20 & 60,16 & 10,55 & \\
\hline & Cina & 2006-2010 & 33,70 & 12,47 & 82,76 & 3,52 & 1,24 \\
\hline & & $2011-2015$ & 49,03 & 13,39 & 75,72 & 9,69 & 1,19 \\
\hline & India & 2006-2010 & 16,73 & 13,20 & 85,24 & 1,11 & \\
\hline & & 2011-2015 & 13,65 & 10,85 & 88,95 & & \\
\hline
\end{tabular}

Sumber: Olahan data penelitian

Keterangan:

Fleksibilitas permintaan pasar ban di Filipina $\left(\varepsilon^{j}\right)$ dimana $j=$ Filipina.

Elastisitas konjektural ban yang di produksi di Filipina $\left(\theta^{j}\right)$ dimana $j=$ Filipina.

Elastisitas konjektural ban yang di ekspor ke Filipina $\left(\theta^{j . h}\right)$ dimana $h=$ Indonesia, Thailand, Cina dan India.

Jenis ban untuk mobil penumpang dengan kode HS 401110. Jenis ban untuk bus, truk, alat-alat berat dengan

Kode HS 401120. Jenis ban untuk sepeda motor dengan kode HS 401140 dan untuk sepeda kode HS 401150.

Cenderung dengan tren menurun. Rata-rata tarif impor ban di Filipina sekitar 30 persen dalam periode 1985 sampai 1997. Tarif impor tersebut turun menjadi rata-rata sekitar 17,42 persen periode 1998 sampai 2003. Tren penurunan tarif terus berlanjut hingga sebesar 10 persen periode 2004 sampai 2010 dan 9,20 persen periode 2011 sampai 2015. Dengan adanya kesepakatn ASEAN Free Trade Area maka tarif tersebut diberlakukan zero tariffs sebagai wujud dari deregulasi perdagangan wilayah ASEAN. Berbagai penelitian sebelumnya menunjukkan peningkatan arus ekspor dan perekonomian pada setuasi hambatan jika tarif diturunkan (Erwidodo, 1999; Arianti dan Lubis, 2011). Industri karet Indonesia dan Thailand diuntungkan dengan kelimpahan bahan baku karet alam, upah tenaga kerja relatif lebih rendah, dan sebaliknya biaya pengapalan (shipping cost) lebih tinggi ke pelabuhan tujuan di Filipina. Sebagian input bahan lainnya (karet sintetis, carbon black, silica dan lain-lain) sebagain besar harus di impor. Sebaliknya industri ban India dihadapkan dengan biaya pengapalan (shipping cost) lebih tinggi ke pelabuhan tujuan di Filipina dan khususnya industry ban Cina dan India juga dihadapkan dengan biaya bahan baku karet alam lebih tinggi karena pengenaan tarif impor karet alam sekitar 20 persen di Cina dan 20 persen di India.

Walaupun Indonesia, Thailand, Cina memiliki kemampuan melakukan mark-up harga relatif sama namun pangsa ekspor Cina jauh lebih besar dari negara pengekspor lainnya. Faktor lain yang dipertimbangkan selain mark-up harga dalam mempengaruhi pangsa ekspor ban di Filipina adalah komposisi ekspor. Komposisi ekspor ban Cina lebih lengkap dibandingkan negara pengekspor lainnya. Cina mengekspor jenis ban mobil penumpang (HS401110), jenis ban bus, truk, alat-alat berat (HS401120), jenis ban sepeda motor (HS401140) dan jenis ban untuk sepeda (HS401150). Negara pengekspor lainnya hanya didominasi jenis ban mobil penumpang dan jenis ban truk, bus, alat-alat berat. Efek dari komposisi ekspor tersebut kemungkinan mendorong peningkatan pangsa ekspor ban Cina di Filipina. Namun kekuatiran begitu kuatnya daya saing produk ban asal Cina di pasar ekspor kemungkinan akan menurun seiring pelemahan ekonomi Cina (slowdown effect) sebagaimana Inoue, et.al (2015) dan Thorbecke (2017). Dalam beberapa tahun terkahir Cina melakukan rebalancing struktur ekonomi dari bertumpu manufaktur dan ekspor ke ekonomi berbasis jasa yang lebih berkelanjutan. Efek dari perubahan tersebut memberikan dampak positif bagi pasar ekspor produk manufaktur negara pesaing termasuk produk ban. 


\section{SIMPULAN}

Dari analisis penilaian kekuatan pasar (market power) menunjukkan kemampuan mark-up harga oleh pengekspor ban Indonesia dan Thailand sama dengan industri domestik di Malaysia. Kemudian kemampuan makr-up harga pengekspor ban Indonesia, Thailnad dan Cina lebih besar dibanding industri domestik di Filipina. Namun demikian pangsa ekspor ban Cina lebih besar di kedua negara tersebut dan kemungkinan hal itu terkait dengan kemampuan Cina memperkaya komposisi ekspor ban.

Indonesia perlu mendorong industri ban domestik untuk meningkatkan kapasitas melalui investasi dan pengembangan teknologi produk ban untuk jenis truk, bus, traktor dan alat berat yang sering digunakan di sektor konstruksi, pertanian, pertambangan dan pelabuhan angkutan barang. Sebagian besar ekspor ban Indonesia hanya bertumpu kepada jenis ban dengan kode 401110 untuk kenderaan penumpang (motor vehicle) kemudian diikuti ekspor jenis ban kode 401140 untuk sepeda motor hanya ke pasar ekspor Filipina. Komposisi jenis ban yang di ekspor Indonesia tertinggal dibandingkan Thailand, Cina, dan India. Peningkatan ekspor disarankan melalui memperbanyak komposisi jenis ban seperti kode HS 401120 untuk kenderaan komersial (commercial vehicle) seperti truck, bus, trailer dan heavy equipment (mining, construction, farming, port lift, reach stacker) serta jenis ban kode HS 401130 untuk transportasi udara atau pesawat terbang. Ekspor ban Indonesia akan terlihat stagnan bila hanya mengandalkan satu jenis ban ke pasar ekspor.

\section{DAFTAR PUSTAKA}

Arianti, R.K, dan A.D. Lubis, 2011.Analisis daya Saing dan Kesiapan Indonesia dalam rangka integrasi ASEAN: Studi kasus automotives, rubber based dan agro based products. Buletin Ilmiah Litbang Perdagangan, 5(1): 1-21

Erwidodo, 1999. Effects of trade liberalization on agriculture in Indonesia: Institutional and structural aspects. The CGPRT Centre. Working Paper No 41.

Ishikawa, J. and K.D. Lee,1997.Backfiring tariffs in vertically related markets. Journal of International Economics, 4(2): $395-423$

Inoue, T, D. Kaya, H.Ohshige, 2015. The Impact of China's slowdown on the Asia Pacific region: An application of the GVAR model. World Bank Policy Research Working Paper. No. 7442. Washington, DC: The World Bank

International Trade Centre, 2020. Export potential map. Reterived April 27, 2020. From http://www.itc.org/trade potential Jeffrey, C and R. Ware, 2000. Industrial Organization: A Strategic Approach. McGraw-Hill Companies, United States of America

Koutsoyiannis, A, 1977. Theory of Econometrics. Second Edition. Macmillan Press. United Kingdom

Kahfi, A.S, 2016. Determinants of Indonesia's exports of manufactured products: A Panel data analysis. Buletin Ilmiah Litbang Perdagangan, 10 (2) : 187-202

Luckstead J, S.Devadoss, R.C.Mittelhammer, 2015. Imperfect cCompetition between Florida and São Paulo (Brazil) orange juice producers in the U.S. and European markets. Journal of Agricultural and Resource Economics, 40(1): $164-178$

Motta, M, 2004. Competition policy: Theory and practice. Cambridge University Press

Trangadisaikul, S, 2011. Oligopsony in the Thai industry: A study of its impacts on the natural rubber industry in Thailand. Thammasat Economic Journal 29(1): 128-169

Thorbecke, W, 2017. How would a slowdown in the people's republic of china affect its trading partners? ADBI Working Paper Series. No. 634. Asian Development Bank Institute United Nation Conference on Trade and Development 1998. Retreived December 17, 2018. From http://www.unctad.org/

UN Comtrade, 2017. Comtrade Database Statistic. Retreived Mei 1, 2017. From http://www.comtrade.org

UN Comtrade, 2020. Comtrade Database Statistic. Retreived July 12, 2020. From http://www.comtrade.org

World Bank. 2017. Database Statistic. Retreived February 10, 2017. From http://www.worldbank.org/ 